\title{
The virtues of fewer directorships
}

Citation for published version (APA):

Bar-Hava, K., Gu, F., \& Lev, B. (2013). The virtues of fewer directorships. Maastricht University, Graduate School of Business and Economics. GSBE Research Memoranda No. 037 https://doi.org/10.26481/umagsb.2013037

Document status and date:

Published: 01/01/2013

DOI:

10.26481/umagsb.2013037

Document Version:

Publisher's PDF, also known as Version of record

\section{Please check the document version of this publication:}

- A submitted manuscript is the version of the article upon submission and before peer-review. There can be important differences between the submitted version and the official published version of record.

People interested in the research are advised to contact the author for the final version of the publication, or visit the DOI to the publisher's website.

- The final author version and the galley proof are versions of the publication after peer review.

- The final published version features the final layout of the paper including the volume, issue and page numbers.

Link to publication

\footnotetext{
General rights rights.

- You may freely distribute the URL identifying the publication in the public portal. please follow below link for the End User Agreement:

www.umlib.nl/taverne-license

Take down policy

If you believe that this document breaches copyright please contact us at:

repository@maastrichtuniversity.nl

providing details and we will investigate your claim.
}

Copyright and moral rights for the publications made accessible in the public portal are retained by the authors and/or other copyright owners and it is a condition of accessing publications that users recognise and abide by the legal requirements associated with these

- Users may download and print one copy of any publication from the public portal for the purpose of private study or research.

- You may not further distribute the material or use it for any profit-making activity or commercial gain

If the publication is distributed under the terms of Article $25 \mathrm{fa}$ of the Dutch Copyright Act, indicated by the "Taverne" license above, 


\section{Maastricht University}

Keren Bar-Hava, Feng Gu, Baruch Lev

The virtues of fewer directorships

$\mathrm{RM} / 13 / 037$

\section{GSBE}

Maastricht University School of Business and Economics

Graduate School of Business and Economics

P.O Box 616

NL- 6200 MD Maastricht

The Netherlands 


\title{
The Virtues of Fewer Directorships
}

\author{
By
}

Keren Bar-Hava*, Feng Gu**, and Baruch Lev ${ }^{* * *}$

January 2013

\footnotetext{
${ }^{*}$ The Hebrew University.

${ }^{* *}$ State University of New York at Buffalo. Corresponding author.

${ }^{* * *}$ New York University, Stern School of Business. The authors are grateful for the helpful comments of workshop participants at INSEAD, National University of Singapore, and New York University.
} 


\begin{abstract}
The "busy director" (multi-directorships) phenomenon increased in recent years, despite the substantial rise in directors' responsibility and time demands. Busy directors are more experienced and better connected than single-firm directors, but also more distracted. The empirical evidence on the tradeoff between these two effects on board effectiveness is mixed. We depart from previous research by examining the reaction to a busy director's resignation by the shareholders of the companies that still keep the director on their board. Our findings indicate that when busy directors resign from a board, the investors of firms that continue boarding the director react positively to the news of the resignation. Investor reaction is more positive when there is a larger demand for the director's services, when the resignation frees up more of the director's time, and when the director is of higher quality. Our analysis suggests that three directorships are perceived optimal by investors. Finally, investors' positive reaction to the resignation of directors from other companies fails to fully capture the governance benefits of such resignation.
\end{abstract}




\section{The Virtues of Fewer Directorships}

\section{Introduction}

Corporate directors drew increased public attention , in the wake of multiple firms' implosions, accounting scandals, and managerial compensation excesses during the first decade of this century (Enron, WorldCom, Lehman Bros., countrywide-a partial list). Directors' independence, expertise (e.g., financial literacy), and the composition of the board's audit and compensation committees were the focus of regulations (Sarbanes-Oxley) and stock exchange standards. The drive by active shareholders to separate the CEO from the board's chair or institute a lead independent director also gains momentum. In contrast, an important aspect of directors' effectiveness - the time and attention they can devote to the job-is largely overlooked by policymakers and the media. The number of directorships a person holds—often along with a day job-is obviously a major determinant of the director's effectiveness, yet there is no regulatory or exchange standard limit, or even guideline, on number of directorships. Not surprisingly, we document a substantial increase in recent years in the multiple-directorship phenomenon.

Our data show that from 1996 to 2010, while firms’ board size decreased, the mean number of directorships per person increased. For example, whereas $26.8 \%$ of all directors held in 1998 two-or-more board positions, this percentage increased in 2010 to almost 40\%. And this occurred during a period of enhanced director responsibilities, significantly increasing the time required for the job: The Wall Street Journal (February 29, 2012) reports a substantial increase in the time devoted by directors to a board, from an annual mean of 150 hours in 2003 to 227 hours in 2011. A 51\% increase! 
There is, however, a tension in the multiple directorship issue. Highly demanded directors-busy, or over-boarded in the governance parlance- - have obviously an above-average reputational capital that enhances their effectiveness. ${ }^{1}$ They are also more experienced in governance than the single directorship person and often bring to bear substantial industry expertise. So, the tradeoffs between the pros of directors' reputational capital/expertise and the cons of distraction and limited attention are a natural subject for research. Yet, the evidence on this issue is somewhat sparse, and the findings mixed. One study, for example, reports no relation between multiple-board directors and firm performance (Ferris et al., 2003), whereas another study finds an association between busy directors and firm underperformance (Fich and Shivdasani, 2006). To cloud the issue further, Field et al. (2011) report a positive association between busy directors and the performance of early-stage firms. Closer to our study, Fich and Shivdasani (2006), in an event study, report that the departure of a busy director from the board triggers a positive abnormal stock return, and vice versa for the appointment of such a director.

Our methodology departs from extant research, in that we examine busy directors' resignations by focusing on the stock price reaction of the firms that still keep these directors on their boards. Focusing on the price reaction of these "retaining firms" provides a clean test of the busy director phenomenon, since the resignation of a director from a board is likely endogenous (directors resigning from failing firms or because of a controversial acquisition), muddying the price reaction to the resignation at the "resigned firm."2 But the likelihood of endogeneity at the "retaining firms" is remote. Our methodology also provides for a larger sample of firms being left with less-distracted directors. Regarding the choice between examining appointments or

\footnotetext{
${ }^{1}$ Studies show that the directors of well-performing firms tend to hold multiple board appointments (Gilson, 1990; Booth and Deli, 1996; Brickley et al., 1999).

${ }^{2}$ For example, Hewllett-Packard's highly controversial acquisition of Compaq in 2002 caused several directors to resign from H-P board.
} 
resignations of busy directors, we chose the latter mainly because extant research focuses on appointments. We thus provide the missing piece of the puzzle. More subtly, when the research issue is the tradeoff between the positive reputation effect of a busy director and the negative distraction effect (discussed above), then for appointments, the distraction effect obviously trumps the reputation effect. The incremental reputation of a busy director being appointed to another board cannot be large but the distraction negatively affects all his/her boards. Hence, the largely unsurprising finding of a negative market reaction to the appointment of a busy director. In contrast, a director's resignation likely affects negatively his/her reputation (rumored to be a trouble-maker, not a team player or abandoning a struggling business). And since the real reasons for the resignation are rarely revealed, a certain cloud surrounds the resigning director. Examining the price reaction of the firms still retaining the resigning director, therefore, provides a more meaningful test of the reputation vs. distraction of busy directors.

Our examination of busy directors' resignation focuses on a sample of 279 directors who resigned from a board position during 2004-2007, while still serving on one or more other boards. We find that the resigning directors have a shorter-than-average tenure at the time of resignation, suggesting the unexpected nature of the resignation. These directors tend to resign from smaller, slower growing, and less profitable companies, while continuing their service on the boards of larger and better-performing firms. The resignation choice of these directors, however, is not associated with increased firm risk, or deterioration in firm performance at the “resigned firms.”

In our test of investor reaction to the busy directors' resignation, we focus on the abnormal stock returns around the announcement date of the resignation at the firms that are still associated with the resigning director. Using standard methodology of event study, we find 
significantly positive and economically meaningful three-day cumulative abnormal returns (CARs) at the firms that still board the busy directors. This reflects investors' expectation, which we corroborate empirically, that the less distracted directors will devote more time and attention to their firm’s governance. Less distraction trumps a potentially diminished reputation.

We also provide evidence on the determinants of investor reaction to busy directors' resignation from another firm. It is more positive when the demand for director services at the "retaining firm” is greater, such as when the firm operates in a volatile environment (technologybased companies), or when it is smaller with higher risks. Investors' reaction is also enhanced when the resignation frees up more of the directors' time. ${ }^{3}$ Finally, investors' reaction at the "retaining firms" increases with the quality of the resigning director, indicated by the director's experience in monitoring firms with complex operations. Directors who are currently CEOs and those who served on audit committees and/or played leadership roles in corporate governance also trigger a more positive reaction at the "retaining firms." Finally, we find that a comprehensive index incorporating the information in all relevant director and firm attributes mentioned above provides a more informative measure of the expected contribution and value of busy directors than the individual attributes. This is of interest to those who wish to exploit directors’ resignation for investment purposes.

We also examine whether investors in the "retaining firms" fully comprehend the benefits of their directors resigning from other firms at the time of resignation. We find that the “retaining firms" exhibit positive abnormal returns subsequent to the resignation, indicating that investors underestimate the benefits of the time and attention freed up by the resignation.

\footnotetext{
${ }^{3}$ For example, a person with two directorships, resigning from one, frees more time than a director serving on four boards, resigning from one.
} 
Finally, given the widely perceived reputational advantage of busy directors and our evidence showing investors’ preference for less distracted directors, an important question for investors, directors, and regulators is whether there exists an optimal number of board seats for busy directors. Our evidence suggests that the optimal level of board commitment from investors' perspective is around three board seats.

The remainder of this paper proceeds as follows. In section II, we briefly review prior literature and highlight the distinguishing aspects of our study. Section III describes the sample and data we use. We report the results of our examination of the market reaction to busy directors' resignation in section IV and multivariate tests are reported in section V. In section VI, we examine whether investors fully comprehend the consequences of directors' resignation, while Section VII investigates whether the resigning busy directors join other boards subsequent to the resignation. We estimate the optimal number of board seats for busy directors in Section VIII. Section IX concludes our study.

\section{Prior Literature on Busy Directors}

Early studies on busy directors argued that the market for directors is efficient and that the demand for directors' services signals their value, reflecting directors' visibility and reputation (e.g., Fama, 1980; Fama and Jensen, 1983; Mace, 1986). Consistent with this view, subsequent studies reported that directors who serve on the boards of successful firms (including the firm's own top executives and other insiders) are more likely to receive multiple board appointments, suggesting a positive association between over-boarding and perceived director quality (e.g., Gilson, 1990; Kaplan and Reishus, 1990; Shivdasani, 1993; Booth and Deli, 1996; Brickley, et al., 1999; Masulis and Mobbs, 2011). 
Subsequent studies directly examined the relation between busy directors and the performance and governance of the firms they serve, yielding mixed results. For example, Ferris et al. (2003) report no relation between the presence of busy directors and firms' performance and conclude that busy directors do not shirk their responsibilities while serving on multiple boards. In contrast, Fich and Shivdasani (2006) report that firms where the majority of the board consists of busy directors have weak corporate governance and relatively poor performance. Beasley (1996) documents a higher probability of accounting fraud among firms with busy directors, and Core et al. (1999) find that firms with busy directors tend to offer excessive executive compensation and have poor performance. Shivdasani and Yermack (1999) suggest that director independence may be weakened when they hold multiple board seats. Further muddying the evidence, Field et al. (2011) find that busy directors contribute positively to young, early-stage firms (e.g., firms shortly before and after IPO). Chandar et al. (2012) report that fewer busy directors on board strengthen financial reporting quality, documenting a nonlinear interaction between the quality and the distraction effect of such directors.

Our study is related to prior research on the market reaction to changes in the level of director over-boarding. Fich and Shivdasani (2006) find a negative market reaction for firms that appoint busy, outside directors, consistent with shareholders' concerns about director distraction. They also report a positive market reaction to the resignation of busy directors. Masulis and Mobbs (2011) document a positive market reaction for firms with inside directors (executives) who receive the first directorship in another firm, and a negative market reaction for subsequent appointments, consistent with the adverse effect of director over-boarding. Our study departs from previous research by focusing on the market reaction to busy directors' resignation at the firms that still retain these directors (while we also document the reaction at the "resigned 
firms”). Our study is also related to existing research on the factors associated with directors' resignation decision. Prior research finds that directors are more likely to resign from firms with unfavorable conditions, such as declining current and future performance, high risk, low director compensation, and forthcoming adverse events (e.g., Yermack, 2004; Asthana and Balsam, 2007; Fahlenbrach et al., 2010b; Bar-Hava and Segal, 2010). We, in contrast, find that busy directors' resignation is not associated with performance and liquidity deterioration. Rather busy directors are more likely to resign from less successful and prominent firms (e.g., smaller and lower growth firms), as keeping a board seat at such firms likely confers less prestige and monetary benefits, which may not justify the heavy workload and responsibilities required for the position.

\section{Sample and Data}

A. Summary Statistics on Directors: 1996 to 2010

We examine the population of all directors covered by Risk Metrics over the period 1996-2010. This database covers a total of 23,259 firms across 15 years, with an average of 1,550 firms per year. The number of directors included in the database also varies by year, with an average of 11,727 directors per year.

Panel A of Table 1 presents statistics for the number of firms, director positions, and directors. Since there are currently about 5,500 public companies listed on U.S. exchanges, the number of firms in Table 1, about 1,500, indicates that Risk Metrics covers less than a third of firms, likely the largest ones. Notably, the average number of directors per firm-board sizedecreased over the period by one director (from 10.3 to 9.36). ${ }^{4}$

\footnotetext{
${ }^{4}$ Prior research suggests that larger boards are less effective in terms of corporate governance (e.g., Yermack, 1996).
} 
The implications of a shrinking board size should be contrasted with major increases in director responsibilities during the period, as the result of more stringent and onerous regulations of corporate governance (e.g., the Sarbanes-Oxley Act enacted in 2002 and various exchange regulations). There is also a heightened investor scrutiny of director negligence in corporate misbehavior, reflected in more directors being targets of shareholder lawsuits and SEC enforcement actions. The pattern of shrinking board size indicates a further increase over time in the workload and responsibilities of directors.

The right two columns of Panel A inform on the mean and standard deviation of the board positions held by a director in each year. ${ }^{5}$ We observe an increase over time in the average number of public company board positions held by a director. In 1998, the average number of board positions held by a director was 1.46, increasing to 1.61 in 2010 .

Panel B provides a detailed account of the increase in the number (percentage) of public company board positions held by a director. In 2010, 6,962 directors (60.3\% of all directors) served on only one board, compared to 7,299 directors (67.1\% of all directors) in 2006 and 9,465 directors (73.2\% of all directors) in 1998; a constantly shrinking percentage of single-board directors. The percentage of directors holding two or three board positions - the lion's share of multi-directorships—has gradually increased from 22.5\% (= $15.3 \%+7.2 \%)$ in 1998 to $29.4 \%$ $(21.6 \%+7.8 \%)$ in 2006 , and further to $35 \%(=24.5 \%+10.5 \%)$ in 2010 - an overall growth rate of 55\%. Notably, the percentage of directors serving on two or three boards jumped in 2007 (from $29.4 \%$ to $34.2 \%$ ), remaining stable thereafter, perhaps related to the financial crisis. Taken together, the data in Panels A and B indicate that directors have become busier over time by

\footnotetext{
${ }^{5}$ The number of public company board positions held by a director also includes public companies that are not covered by Risk Metrics.
} 
taking more board positions. The growing popularity of busy directors in board rooms may reflect increased demand for qualified, experienced directors during challenging economic times.

Panel C of Table 1 shows a substantial increase in the age of directors: the mean (median) age of directors was 58.80 (59) in 1996 vs. 62.14 (63) in 2010. To the extent that director age is positively associated with experience and expertise, this increase is consistent with firms' preferences for more experienced reputable directors. Panel D, however, shows a nearly flat pattern of director tenure over time. The mean (median) director tenure is 8.99 (6) over the period of 1998-2010.

\section{B. Descriptive Information on the Resigning Busy Directors}

We define busy directors as those who serve on the boards of two or more public companies, a threshold for classifying a director as busy which is lower than that of prior studies. We employ this lower threshold to include a larger sample to assess whether the effect of busy directors extends to a broader set of directors than previously examined. Our sample, which focuses on busy directors' resignations, is derived from the sample of all directors' resignations used in the study of Bar-Hava and Segal (2010). This study is based on a comprehensive search across all 8-K reports included in the Edgar database for the period of 2004-2007. Bar-Hava and Segal identified 1,054 cases of director resignations for which there were no confounding events over a 3-day window of the resignation announcement. Of this initial sample, we retain a final sample of 279 busy directors who served on two or more boards of public companies before the resignation. We also collect from the proxy statement information on the director's role as a CEO (of another firm), whether he/she served on the audit committee, or in a leadership role in 
governance and control (chairing the corporate governance committee and/or nominating committee).

Table 2 provides summary statistics for these 279 resigning directors. The number of resignations by busy directors varies from year to year, ranging from 36 resignations in 2004 to 114 resignations in 2006. Panel A reports the number of all types of board positions, including public companies, private firms, and not-for-profit organizations, that are still held by the busy director after the resignation. The mean and median number of boards kept by the resigning directors are 3.2 and 3.0, respectively. Thus, these directors keep significant board responsibilities even after their resignation.

Panel B reports the distribution of the public company boards kept by the busy director after the resignation. The mean (median) number is 1.828 (1.000), indicating that a large number of the busy directors in our sample continue to hold multiple board positions at other public companies. Compared to the population of all directors reported in Table 1, Panel A, the resigning busy directors included in our sample hold a greater number of board positions. For example, on average, these directors serve on 1.991 (2.991) boards after (before) the resignation in 2006, whereas the average number of board positions for all directors is 1.49 in the same year (Table 1, Panel A).

Panel $\mathrm{C}$ reports the age of busy directors in the year of resignation. The mean (median) age is 56.118 (57) years across all sample years. Compared to the population of all directors reported in Table 1, Panel C, whose mean (median) age ranges from 59.36 to 61.60 (60 to 62) during the same period (2004-2007), the resigning busy directors included in our sample are younger by 3-4 years. Thus, the resignation doesn't appear to be age-related. Panel D, Table 2, reports the statistics for director tenure, measured as the number of years of service rendered by 
the busy directors until resignation. The mean and median director tenures are 5.004 and 4 years, respectively across all sample years, which is substantially shorter than the average tenure of all directors during the same period: mean (median) tenure for all directors is 8.59 years (6 years) for the period of 2004-2010. To the extent that investors expect directors to serve a standard term, resignation by directors with less than the average tenure is likely unexpected and thus conveys newsworthy information. Table 2, Panel E shows that the equity holding by busy directors included in our sample is relatively small: the majority (82.4\%) of the directors holds less than $1 \%$ of the firm's equity.

Table 3 lists the reasons cited for the busy directors' resignation. We obtained this information directly from firms' 8-K filings of the announcement of the resignation. We classify the cited reasons for the resignation into 11 non-overlapping categories. The data shows that approximately $30 \%$ of the resignation filings report no specific reason, whereas slightly more than a quarter $(26.1 \%)$ of the resignations are characterized as no-disagreement between the director and the firm. The next three most commonly cited reasons are the director's other commitments (17.56\%), personal reasons (10.04\%), and the requirement to meet independence standards (7.53\%). Across all sample years, these five types of reasons account for $90 \%$ of the resignations. The distribution of resignation reasons is similar across sample years.

\section{Characteristics of the "Resigned" and "Retaining" Firms}

Table 4 provides information on the two groups of firms that are associated with the resigning busy directors: firms from which the directors resigned (“resigned firms” hereafter), and the firms that still retain the busy directors ("retaining firms" hereafter). There are 279 resigned firms in our sample, and 445 retaining firms. Table 4 reports sample firms' industry 
membership based on two-digit SIC. The top five industries of the resigned firms are: chemical and pharmaceutical products (12.5\%), computer software and data processing (11.5\%), electrical and electronics (9.3\%), insurance carrier (6.5\%), and communication (5.7\%). Together these five industries account for $45.5 \%$ of the resigned firms sample. Except for insurance carriers, these industries are typically technology-driven and intangibles-intensive businesses. A similar, yet less marked pattern of industry concentration is observed for the 445 retaining firms. These same five industries account for $36.6 \%$ of the sample of the retaining firms. The higher concentration of technology-based industries in the sample of resigned firms suggests that the relatively high risk and operational complexity associated with monitoring technology-based companies may play a role in busy directors' decision to resign. However, relative to all firms in the industry (right-hand columns of triplets), rather than relative to the total sample, there isn't a significant industry concentration in the "resigned" or "retaining” samples.

In Table 5, we compare key financial characteristics of the resigned and retaining firms, respectively. A comparison based on the median values indicates that busy directors tend to resign from smaller firms (by total assets), less profitable firms (lower ROA), lower growth firms (lower market-to-book), firms with lower cash flows from operation deflated by average total assets (CFO), and firms with lower capital investment (deflated by total assets), than the “retaining” firms. The resigned firms also have lower leverage ratios (long-term liabilities to total assets) and higher current ratios. ${ }^{6}$ Notably, at the median, the resigned and retaining firms have similar changes in key indicators of financial health, including changes in ROA, CFO, leverage ratio, and current ratio. Taken together, these comparisons suggest that directors tend to

\footnotetext{
${ }^{6}$ The lower leverage and higher liquidity of the resigned firms may be related to the higher concentration of technology industries (e.g., electronics and software) among these firms. Because of the high risk associated with technology firms, they tend to have less debt for both the short-term and long-term.
} 
resign from less successful and prominent firms, although performance or liquidity deterioration doesn't seem to be a resignation motive. If director resignation is mainly motivated by heavy workload, it makes sense to resign first from smaller-lower director compensation—and less prominent firms, as the evidence suggests.

\section{Investors' Reaction to the Resignation of Busy Directors}

\section{A. Overall Reaction}

We hand-collect the announcement date of director resignation from the resigned firms' 8-K filings, which provide the first public disclosure of the director's resignation. We follow the standard approach of event study (e.g., Brown and Warner, 1985) to measure the three-day (i.e., days $-1,0$ and +1 , centered on the announcement date) abnormal stock returns of the retaining firms still boarding the resigning directors. For each day during the event period, abnormal returns are measured as the difference between the firm's raw return and the return on the size decile portfolio to which the firm is assigned. We sum up the abnormal returns across the three days to compute cumulative abnormal returns (CARs) for each retaining firm. We then compute the mean value of the three-day CARs across all retaining firms and assess its statistical significance on the basis of the $p$-values determined by following the procedure of Brown and Warner (1985). ${ }^{7}$

Table 6 provides the stock price reaction to the news of busy directors' resignation. In Panel A, we report the mean of the three-day CARs and their $p$-values for all of the 360 retaining firms that have the stock returns data required by our test. The mean three-day CAR is $0.40 \%$,

\footnotetext{
${ }^{7}$ Under this approach, the standard deviation of the mean cumulative abnormal returns is estimated by using 239 days of return data (days -233 through days -6 relative to the announcement day). The test statistic controls for cross-sectional dependence in the abnormal returns because a portfolio average abnormal return is used to estimate the standard deviation.
} 
significant at the 0.051 level, one-tailed test. Thus, investors in the retaining firms react positively to the news of busy directors' resignation in other firms. This is consistent with an appreciation of the increased time and attention that directors can devote to the retaining firms after they reduce their other board commitments and responsibilities.

\section{B. Conditional investor reaction}

The overall mean reaction to director resignation obscures the individual factors affecting the reaction. To flesh out these factors, we selected several director and firm attributes for closer inspection. We posit that investors' (in the retaining firms) valuation of the time and attention released by director resignation is affected by: (1) the demand for director services (e.g., the need to monitor and advise inexperienced managers), and (2) the supply of high quality directors. Investor reaction to busy directors' resignation and its implications is likely more positive when the demand for director services is high and when the resigning directors have special capabilities to fulfill their mission.

The demand for director monitoring and advisory services is likely greater when the retaining firm operates in particularly challenging and uncertain sectors, such as technologybased industries, where barriers to entry are low and the pace of innovation quick. The assets of these firms are mostly intangible (patents, trademark, unique business processes), being particularly risky and hard to manage. The demand for director guidance is also greater for startups and smaller firms, generally having greater growth prospects and facing higher risk (more likely to operate in emerging industries and new markets). Accordingly, we expect more positive investor reaction to the news of busy directors' resignation when the retaining firm operates in technology sectors and/or is a smaller firm. 
When a busy director resigns, a certain amount of time and attention is freed up and becomes available to the boards of the retaining firms. The amount and value of this released time is likely greater when the director had serious responsibilities in the resigned firm's board. We also conjecture that director responsibilities are greater when the firm experiences performance problems, which we proxy by earnings decreases, since earnings decreases are symptoms of higher director involvement. Directors can also devote more time and attention to the retaining firm if they served on fewer boards. For example, a director who keeps two board seats after the resignation frees up 1/3 of his/her total available time, whereas a director who keeps 4 board seats after the resignation frees up only 1/5 of his/her time. Accordingly, we predict a more positive market reaction when the busy director resigned from the board of an earnings-decreasing firm, or served on fewer boards after the resignation.

The quality of director services, however, is less straightforward to observe and measure. We infer this attribute from relatively objective indicators, based on the job description and the director's knowledge and skills. Because certain dimensions of directors' knowledge and skills are industry-specific (industry expertise), the quality of director's contribution is likely greater when the "retaining firms" are in the same industry as the "resigned firms." Therefore, we expect a more positive market reaction to resignation when the "retaining firm" is from the same industry as the "resigned firm." The quality of director service is also related to the number of analysts following the resigned firm, because firms followed by many analysts tend to have more involved operations, invest more in complex assets (e.g., intangibles), and face greater investor scrutiny, thereby likely appointing more experienced and capable directors. ${ }^{8}$ Thus, we expect a

\footnotetext{
${ }^{8}$ Barth et al. (2001) find that analyst coverage and effort are greater for firms that invest more in intangible assets, which are more complex and more difficult to manage than tangible assets.
} 
more positive market reaction when the director resigns from a firm with a larger analyst following.

Finally, the intrinsic capabilities and quality of directors are also indicated by their job responsibilities as a top executive or by his/her board responsibilities. Directors who currently serve as a CEO of another firm, or those who served on the audit committee, or played a leadership role in corporate governance of the resigned firm (e.g., financial experts and experts on governance) will likely contribute more to the retaining firms than directors without these credentials. $^{9}$ When a director relinquishes the heavier responsibilities of serving on an audit committee or leading corporate governance (lead director), there is also likely a larger time release benefitting the retaining firm. Therefore, we expect a more positive market reaction when the resigning director is a CEO, or served on the audit committee or chaired the corporate governance committee and/or nominating committee of the resigned firm.

\section{Investors' reaction by determinants}

Panels B through E of Table 6 report on univariate tests examining the market reaction of the "retaining firms" investors to busy directors' resignation, conditioned on specific determinants. For expositional purposes, we classify these determinants into three groups: (1) characteristics of the "retaining firms," creating demand for director services, (Panel B), (2) characteristics of the "resigned firm" (Panel C), and (3) capabilities of the resigning busy directors (Panel D). In Panel E, we consider the joint effects of all determinants.

In Panel B, we first partition the sample of 360 "retaining firms" by whether the firm is from one of six technology industries: chemical and pharmaceutical, computer and machinery,

\footnotetext{
${ }^{9}$ Prior research finds that CEOs are particularly desirable choices of outside directors because of their experience as executives (e.g., Fahlenbrach et al., 2010a), and that directors who are also financial experts are more valuable than others (e.g., DeFond et al., 2005).
} 
electrical and electronics, transportation equipment, medical and scientific instrument, and computer software, or other industries. The results show that the three-day CARs-investor reaction—for technology firms are significantly larger than those for other firms $(1.38 \%$ vs. $-0.13 \%)$, corroborating our conjecture that the more complex tech and science-based firms benefit more from the time released by the resigning directors. In B2, we divide the sample of retaining firms into two size groups, based on whether the firm's market value is below or above the median market value of all retaining firms. The results indicate that market reaction to the busy directors' resignation is significantly larger for smaller firms than for larger ones $(0.72 \% \mathrm{vs}$. 0.09\%), indicating the larger benefits to smaller firm, often managed by inexperienced managers with smaller support staff, from directors' released time. In B3, we partition the retaining firms on whether the resigning director is from the same industry or not. Consistent with our prediction, we find a significantly more positive market reaction when the retaining firm is from the same industry as the resigned firm ( $0.96 \%$ vs. $0.23 \%)$, indicating more valuable industryspecific expertise.

Panel C presents investors' reaction in the retaining firms partitioned by whether the resigned firm experienced earnings decreases in the recent year (C1) and whether the resigned firm has a large number of analyst following (C2). Consistent with our predictions, we find that there is a more positive market reaction when busy directors resign from firms experiencing earnings decreases $(0.86 \%$ vs. $0.14 \%)$, indicating a substantial release of director's time after resigning from a troubled company, and when they resign from firms with a larger analyst following $(0.59 \%$ vs. $-0.07 \%)$. In Panel $\mathrm{D}$, we partition the sample of retaining firms by the attributes of the resigning directors: in (D1) the number of boards served by the director after resignation (no more than 4 vs. more than 4), (D2) whether the director is a CEO of another 
company (currently being a CEO vs. not currently being a CEO), (D3) whether the director served on the audit committee of the "resigned firm," and (D4) whether the director chaired the corporate governance committee and/or nominating committee of the "resigned firm." Consistent with our predictions, we find that the market reaction is significantly more positive when the resigning directors serve on fewer boards $(0.65 \%$ vs. $-0.17 \%$ in $\mathrm{D} 1)$-more time released — when the director is a CEO (1.01\% vs. $0.27 \%$ in D2)—more qualified —when the director served on the audit committee (1.31\% vs. $-0.06 \%$ in D3), or when the director chaired the corporate governance committee and/or nominating committee of the resigned firm $(2.00 \%$ vs. $0.34 \%$ in D4)—all indicating high quality and experience of the resigning directors.

Taken together, the univariate tests lend consistent support to our prediction that investors in the retaining firms value the newly released time and attention of the resigning directors more highly when there is a greater demand for the director's service at the retaining firms (high tech, small, or same-industry firms), when more time is released by the resignation (resigning director served on fewer boards), and when the resigning director possesses higher qualifications and experience (a CEO, lead director, member of audit committee).

In Panel E, we examine whether a joint consideration of the nine director and firm characteristics reported in Panels B through D is more powerful in explaining market reaction to the busy directors' resignation than the individual attributes. To incorporate the information from all nine attributes, we perform a principal component analysis and use the first two principal components as our aggregate indicators for the expected contribution and value of the resigning directors. In this analysis, all director and firm characteristics are included as dummy 
variables, except for firm size, which is measured as the firm's market value. ${ }^{10}$ We use the two principal components reflecting the nine attributes to partition the "retaining firms" to quartiles on a $4 \times 4$ table. That is, we sort all "retaining firms" into quartiles based on these two indicators, respectively. We focus on the main diagonal at the intersection of these quartiles which reflects the joint effects of the two principal components. By construction, the highest-highest (lowestlowest) quartile consists of firms that are simultaneously classified into the highest (lowest) quartile of the first principal component and the highest (lowest) quartile of the second principal component (i.e., the intersection of these two quartiles). Low-medium is for the second lowest quartile, whereas medium-high is for the second highest quartile. Thus, moving from the highest-highest quartile to the lowest-lowest quartile gives a sorting of the "retaining firms" in a descending order of expected contribution and value of the resigning directors.

The data in Panel E indicate that the market reaction to busy directors' resignation indeed varies positively with the aggregate expected contribution and value of the director. Firms classified as expected to benefit most from the resigning directors (i.e., the highest-highest quartile) earned three-day mean CAR of $4.07 \%$ (significant at the 0.034 level), whereas firms associated with the least contributing resigning directors (i.e., the lowest-lowest quartile) earned three-day CAR of only $0.09 \%$ (statistically insignificant). The mean return spread between the most valuable and least valuable directors-almost $4 \%$ in three days-is statistically and economically meaningful, indicating that incorporating the nine director and firm attributes provides a more informative measure for the contribution and value of the resigning directors.

\section{Multivariate Analysis}

\footnotetext{
${ }^{10}$ Our results are similar when we use a dummy variable to distinguish firms with above-median market value from those with below-median market value.
} 
In Table 7, we report the multivariate estimates based on the regression of market reaction to resignation on the nine director and firms characteristics presented in Table 6 , and the two principal components derived from these nine characteristics. Following the structure of Table 6, we include these characteristics in groups of three separate regressions (Models 1, 2, and 3) and all together in one regression (Model 4). In Model 5, we include the two principal components — joint effect of determinants—as the sole independent variables. Regression models 1-3 indicate that, with the exception of the industry overlap, all the variables hypothesized to affect market reaction are statistically significant. The two principal components (Model 5) are also statistically significant. Model 4 indicates that these nine director and firm characteristics combined explain $7.6 \%$ of the variability of the market reaction to busy directors' resignation. In all, the results from our multivariate analysis in Table 7 are consistent with the univariate results presented in Table 6. The multivariate results further substantiate our conclusion that decreasing the load of busy directors is favored by investors, and that various predictable director and firm characteristics related to the demand and supply of director services are value-relevant to the investors of retaining firms.

\section{A Reaction to Time and Attention Released or a Signaling Story?}

We conjectured so far that the retaining firms investors' positive reaction to the resignation of busy directors is triggered by the value of time and attention released by the resignation. Our conditional analysis, reported in Table 6, supports this conjecture (e.g., a stronger reaction when more time is released or when the resigning director is highly qualified). It can nevertheless be argued that investor reaction in the retaining firms primarily reflects the signal provided by the resigning director: negative for the resigned firm (abandoning a sinking 
ship), and, by default, positive for the retaining firms (staying with winning enterprises). Obviously, a negative investor reaction to the resignation at the "resigned firms" will support a signaling scenario. Consistent with our test of market reaction at the retaining firms, we use the standard methodology of event study to measure investor reaction at the resigned firms, with the three-day cumulative abnormal returns (CARs) of the stocks of the resigned firms around the announcement date of the resignation (i.e., days $-1,0$, and +1 centered on the event date).

Table 8 provides the stock price reaction for the resigned firms. We report the mean and median value of the three-day CARs and the associated $p$-value for the 238 resigned firms that have the stock return data required by our test. However, we find that for the resigned firms the mean three-day CARs related to the directors' resignation is a positive $0.86 \%$ (significant at the 0.002 level, one-tailed). The median three-day CAR is also positive $(0.22 \%)$ and statistically significant at the 0.018 level (one-tailed). These results, consistent with prior evidence (e.g., Fich and Shivdasani, 2006), indicate that investors of the resigned firms also welcome the resignation of busy directors who are distracted and likely less effective in terms of corporate governance. We thus find no evidence of a signaling effect of the resigning directors.

\section{Do Investors Fully Comprehend Directors’ Resignation?}

We saw that shareholders of the retaining firms react positively to the resignation of busy directors from other firms' boards. But does this 3-day market reaction fully reflect the benefits of the released time and attention of the resigning directors? This question has obvious implications for the extent to which investors comprehend market events and for capital markets efficiency in general. While some investors in the retaining firms obviously react in time to director resignation from other firms, the majority of investors may not even be aware that 
directors of their firms have now more time and attention to devote to their firms. Put differently, is the "busyness" of directors an important factor that investors should monitor? If the released time of the resigning directors is valuable, and not fully comprehended at resignation time, then the stocks of the retaining firms will earn positive abnormal returns subsequent to the resignation announcement.

We examine this issue by using the Fama-MacBeth (Fama and MacBeth, 1973) monthly methodology to record whether busy directors' resignation is indeed associated with long-run abnormal returns at the retaining firms. The dependent variable of the regression is the retaining firms' monthly returns over next 12-months following the resignation (excluding the resignation month). The independent variables are: the logarithm of the firm's market value ( $\operatorname{Ln}(\mathrm{MV}))$, the logarithm of the firm's book-to-market ratio $(\mathrm{Ln}(\mathrm{B} / \mathrm{M}))$ at the end of the most recent fiscal-year, the return of the prior month (Ret_1), the return of the previous 12-month period (Ret_2), the return of the previous 36-month period (Ret_3), and a dummy variable for busy directors' resignation (RESIGN), which equals one if the firm keeps a director who recently resigned from another firm and zero otherwise. We also include in the regression the director value as measured by indicators \#1 and \#2, which are the first two principal components derived from the nine director and firm characteristics presented in Table 6.

This regression includes firms that keep the resigning busy directors (i.e., the retaining firms) along with all other firms. Accordingly, the dummy variable for busy directors' resignation (RESIGN) and the two variables for the director value take the value of zero for all firms other than the retaining firms. For each event of director resignation, the retaining firms' monthly returns of the subsequent 12 months are used as the dependent variable of the regression. Because the first event of resignation by busy directors included in our sample is in 
February 2004 and the last event is in December 2007, the future return period included in the regression is from March, 2004 through December, 2008 and spans a total of 58 months.

We report the results of the Fama-MacBeth monthly regression in Table 9, Panel A, noting that there are significant positive abnormal returns associated with the resignation of busy directors (Model 1 and Model 2). In Model 1, the mean coefficient on the dummy variable of busy directors' resignation (RESIGN) is 0.013 (statistically significant at the 0.019 level). Thus, compared to other firms, the retaining firms earn, on average, monthly abnormal returns of $1.3 \%$, equivalent to $16.8 \%$ on an annual basis - an economically significant return for the retaining firms. The mean coefficients on the director value indices are also significantly positive (Model 2), indicating even higher future abnormal returns associated with director resignation. Thus, investors in firms whose directors became "less busy" do not fully appreciate the value of this event at the resignation time. This is not entirely surprising, since it is hard to believe that most investors monitor closely directors' employment in other firms. But it does create a profit opportunity from watching directors' "busyness.”

We employ the same methodology of the Fama-MacBeth monthly regressions to examine the one-year-ahead returns of the resigned firms. This regression also includes the resigned firms and all other firms. Control variables include Ln(MV), Ln(B/M), Ret_1, Ret_2, and Ret_3. The variable of interest is once more RESIGN, a dummy variable that takes the value of one for the resigned firms and zero otherwise. The set-up of this regression is similar to that of the retaining firms in Panel A. For each event of director resignation, the resigned firms' monthly returns of the subsequent 12 months are used as the dependent variable of the regression. The monthly regression period is from March, 2004 through December, 2008, spanning a total of 58 months. 
We report the estimates of this test in Table 9, Panel B. In Model 2, the mean coefficient on the dummy variable of busy directors' resignation (RESIGN) is 0.002, statistically insignificant. Thus, unlike the case for the retaining firms, there are no future abnormal returns for the resigned firms, suggesting that investors of the resigned firms react fully to the news of busy directors' resignation when it is announced. This too is not surprising, since shareholders are generally aware of director resignation in their firms, in contrast with resignations from other firms.

\section{Do the Resigning Directors Become More Available and More Involved?}

We conjectured above that a busy director's resignation frees time and attention to devote to other firms (retaining firms). But, does this happen in reality? To provide direct evidence on the effects of resignation on the director's availability and contribution to the retaining firm, we examine changes in director responsibilities at the retaining firms following the director's resignation from the resigned firm. We record director responsibilities at a given board by his/her role in key committees, such as the audit committee, compensation committee, and nominating/governance committee. In particular, directors who become the chair or member of additional committees after resignation have greater board responsibilities and likely make greater contributions to the board. Table 10, Panel A reports the number and type of committees served by the resigning director at the retaining firm in the year immediately before the resignation (year $t-1$ ), the year immediately after the resignation (year $t+1$ ), and the difference. The data results are for 134 out of the 445 (30\%) retaining firm boards for which complete information for director responsibilities is available in Risk Metrics for both year $t-1$ and year 
$t+1 .^{11}$ Focusing on directors who chair audit committees and/or compensation committees, two board structures of critical importance to corporate governance, we find a significant increase after the director's resignation ( 0.239 chairs per director in year $t-1$ vs. 0.314 in year $t+1)$. Thus, there is a $30 \%$ increase in the director's involvement in audit committees and compensation committees following the resignation. We also find significant increases in the number of directors serving on compensation committee and nominating/governance committee after the resignation. ${ }^{12}$ Combining all committees and board positions, our results show a significant increase in board responsibilities by directors after their resignation (1.425 for year $t-1$ vs. 1.590 for year $t+1$ ). We thus provide direct evidence explaining the positive, short- and long-term, investor reaction to the resignation.

Another aspect of the resignation-whether the resigning director soon joins another board — should also be examined, since if the resigning directors soon join other boards, then no time is released by the resignation. To examine this question, we track the number of board positions held by the resigning directors in the year subsequent to the resignation. We focus on 210 directors who have complete information available for the post-resignation period of 20052008, and examine whether the number of their directorships has changed. The baseline for this examination is the number of directorships immediately after the resignation (year $t$ ). Of our sample, 69 directors were not included in this examination due to three reasons: (1) the retaining firm merged with another firm during the post-resignation period, (2) the director left the board

\footnotetext{
${ }^{11}$ The exclusion of a retaining firm in Risk Metrics for a given year can be due to a variety of reasons, including (1) non-coverage of the firm in Risk Metrics, (2) merger and acquisition involving the firm, and (3) other changes involving the firm (e.g., delisting and bankruptcy). Because Risk Metrics provides information on nominating committee chair and governance committee chair after 2007, we exclude directors' role as the chair of these two committees from this examination.

${ }^{12}$ The limited and insignificant increase in the number of directors who chair audit committee is likely in part due to the requirement at many firms that only directors with financial expertise, who represent only a minority among all directors, can serve in this capacity.
} 
and became a senior executive of the firm (e.g., the general counsel or chief information officer), or (3) no financial filing of the retaining firm was found in the post-resignation period. The results of this test are reported in Table 10, Panel B, showing that the mean number of board positions kept by the director is 1.881 immediately after the resignation (year $t$ ), and 1.556 in the year following the resignation (year $t+1$ ). Table 10, Panel B shows that this decrease in mean board membership is statistically significant at the 0.0001 level. Specifically, we find that 54 (155) directors further reduced (did not change) the number of their directorships after the resignation, whereas only 1 director acquired another directorship after the resignation. Thus, our results demonstrate that the vast majority of resigning directors indeed became less distracted, further buttressing our findings of positive market reaction to resignation. The decrease in the resigning directors' "business" should be contrasted with the general increase in multi-directorships observed in Table 1.

Taken together, the results in Table 10 indicate that in the post-resignation period directors significantly increase their board responsibilities and leadership at retaining firm boards and also remain focused on current board responsibilities by refraining from obtaining other board seats. These effects support the view that less distracted directors are beneficial to corporate governance.

\section{The Optimal Number of Board Seats}

Our findings indicate that reducing the number of multiple boards increases the effectiveness of directors. Early research on the reputation capital of busy directors, however, argued that directors who serve on multiple boards are in high demand because of their experience and tested qualifications (e.g., Fama, 1980). These conflicting views of the 
desirability of busy directors raise the question of the optimal number of board seats that busy directors should have. We provide insight to this question from investors' perspective, by examining the extent to which the market reaction to busy directors' resignation varies with the number of board seats kept by the director after the resignation. We accordingly modify the regression of Table 7 to include indicatorvariables for the varying number of board seats after the resignation, ranging from two to eight or more seats. This regression allows us to estimate the incremental price effect associated with the number of board seats after the resignation of busy directors. We also control for the other eight determinants of investor reaction to resignation documented in Table 7, by including the first two principal components of these eight determinants (“Modified director value index \#1 and \#2”) in the regression.

Table 11 reports the results of estimating the optimal number of board seats for busy directors. We find that the coefficients on the number of board seats after resignation vary considerably, indicating a non-linear incremental effect. Investors' response coefficients are positive for up to four seats, and become negative for higher seat numbers. The class of resigning director keeping three board seats has the largest and most significant coefficient (0.015, significant at the 0.023 level), whereas other seat numbers have statistically insignificant coefficients. This pattern of coefficient estimates suggests that the benefits placed by investors on busy directors tend to peak at three to four directorships.

\section{Conclusions}

This study investigates the desirability of multi-directorships by examining the impact of resignation of busy directors on the firms that still board these directors. This study is timely because our data shows a generally increasing trend of multi-directorships. We find that the busy 
directors resign from smaller, less profitable firms. Our main finding is that investors in firms that keep busy directors after they resign from another firm react positively to the resignation. This is consistent with a positive contribution of the time and attention released after the director cuts back on his/her board commitments. Our results further demonstrate that busy directors are valued by investors according to the demand for their services, the time availability of the director, and the director's experience and intrinsic quality. On average, investors seem to view three to four board seats as the optimal level of board commitment. We also find that investors in the retaining firms do not fully comprehend the benefits of the less distracted directors after resignation. Taken together, our results suggest that the increasing trend of busy directors is detrimental to effective corporate governance. These findings should be of interest to boards nominating committees, to shareholders approving or challenging directors' nominations, and possibly to regulators. 


\section{REFERENCES}

Asthana, S., Balsam, S., 2007. Determinants of outside director turnover. Working paper, University of Texas at San Antonio.

Bar-Hava, K., and D. Segal, 2010, Do outside directors tell the truth, the whole truth, and nothing but the truth when they resign?, Working paper, The Hebrew University.

Barth, M., R. Kasznik, and M. McNichols, 2001, Analyst coverage and intangible assets, Journal of Accounting Research 39, 1-34.

Beasley, M. S., 1996, An empirical analysis of the relation between the board of director composition and financial statement fraud, The Accounting Review 71, 443-465.

Booth, J., and D. Deli, 1996, Factors affecting the number of outside directorships held by CEOs, Journal of Financial Economics 40, 81-104.

Brickley, J., J. Linck, and J. Coles, 1999, What happens to CEOs after they retire? New evidence on career concerns, horizon problems, and CEO incentives, Journal of Financial Economics 40, 81-104.

Brown, S., and J. Warner, 1985, Using daily stock returns: the case of event studies, Journal of Financial Economics 14, 3-31.

Chandar, N., A. Klein, and X. Zheng, 2012, Do multiple directorships for audit committee members influence financial reporting quality? Working paper, New York University.

Core, J., R. Holthausen, and D. Larcker, 1999, Corporate governance, chief executive officer compensation, and firm performance, Journal of Financial Economics 51, 371-406.

DeFond, M., R. Hann, and X. Hu, 2005, Does the market value financial expertise on audit committees of board of directors? Journal of Accounting Research 43, 153-193.

Fahlenbrach, R., A. Low, and R. Stulz. 2010a, Why do firms appoint CEOs as outside directors? Journal of Financial Economics 97, 12-32.

Fahlenbrach, R, Angie, L., Stulz, R.M., 2010b, The dark side of outside directors: do they quit when they are most needed? Working paper.

Fama, E., 1980, Agency problems and the theory of the firm, Journal of Political Economy 88, 288-307.

Fama, E., and M. Jensen., 1983, Separation of ownership and control, Journal of Law and Economics 26, 301-25. 
Fama, E., and J. MacBeth, 1973. Risk, return, and equilibrium-empirical tests, Journal of Political Economy 81, 607-636.

Ferris, S., M. Jagannathan, and A. Pritchard, 2003, Too busy to mind the business? Monitoring by directors with multiple board appointments, Journal of Finance 59, 1087 -1111 .

Fich, E., 2005, Are some outside directors better than others? Evidence from director appointments by Fortune 1000 firms, Journal of Business 78, 1943-1971.

Fich, E., and A. Shivdasani, 2006, Are busy boards effective monitors, Journal of Finance 61, 689-724.

Field, L., M. Lowry, and A. Mkrtchyan, 2011, Are busy boards detrimental? Working paper, Pennsylvania State University.

Gilson, S., 1990, Bankruptcy, boards, banks, and blockholders, Journal of Financial Economics 26, 355-387.

Kaplan, S., and D. Reishus, 1990, Outside directorships and corporate performance, Journal of Financial Economics 27, 389-410.

Mace, M., 1986, Directors: myth and reality, Harvard Business School Press, Boston, MA.

Masulis, R., and S. Mobbs, 2011, Are all inside directors the same? Evidence from the external directorship market, Journal of Finance 66, 823-872.

Shivdasani, A., 1993, Board composition, ownership structure and hostile takeovers, Journal of Accounting and Economics 16, 167-198.

Shivdasani, A. and D. Yermack, 1999, CEO involvement in the selection of new board members: an empirical analysis, Journal of Finance 54, 1829-1853.

Yermack, D., 1996, Higher market valuation of companies with a small board of directors, Journal of Financial Economics 40, 185-211.

Yermack, D., 2004. Remuneration, retention, and reputation incentives for outside directors. Journal of Finance 59, 2281-2308. 
Table 1

Descriptive Statistics for Directors: 1996-2010

\begin{tabular}{|c|c|c|c|c|c|c|c|}
\hline \multicolumn{8}{|c|}{ Panel A. Numbers of firms, director positions, and directors by year } \\
\hline \multirow[b]{2}{*}{ Year } & \multirow[b]{2}{*}{ \# firms } & \multirow[b]{2}{*}{$\begin{array}{l}\text { \# director } \\
\text { positions }\end{array}$} & \multirow[b]{2}{*}{ \# directors } & \multicolumn{2}{|c|}{ \# directors per firm } & \multicolumn{2}{|c|}{$\begin{array}{l}\text { \# public company board } \\
\text { positions per director }\end{array}$} \\
\hline & & & & Mean & $\begin{array}{l}\text { Standard } \\
\text { deviation }\end{array}$ & Mean & $\begin{array}{r}\text { Standard } \\
\text { deviation }\end{array}$ \\
\hline 1996 & 1444 & 14867 & 11634 & 10.30 & 3.37 & NA & NA \\
\hline 1997 & 1584 & 15631 & 11977 & 9.87 & 3.24 & NA & NA \\
\hline 1998 & 1770 & 17048 & 12936 & 9.63 & 3.15 & 1.46 & 0.93 \\
\hline 1999 & 1804 & 17420 & 13323 & 9.66 & 3.21 & 1.51 & 0.95 \\
\hline 2000 & 1756 & 16675 & 12946 & 9.50 & 3.14 & 1.48 & 0.91 \\
\hline 2001 & 1797 & 16669 & 13034 & 9.28 & 3.05 & 1.48 & 0.91 \\
\hline 2002 & 1439 & 13499 & 10681 & 9.38 & 2.84 & 1.49 & 0.91 \\
\hline 2003 & 1472 & 13792 & 10959 & 9.37 & 2.61 & 1.48 & 0.89 \\
\hline 2004 & 1477 & 13820 & 11047 & 9.36 & 2.57 & 1.51 & 0.89 \\
\hline 2005 & 1455 & 13582 & 11018 & 9.33 & 2.44 & 1.48 & 0.86 \\
\hline 2006 & 1413 & 13372 & 10879 & 9.46 & 2.39 & 1.49 & 0.84 \\
\hline 2007 & 1431 & 13338 & 10991 & 9.32 & 2.43 & 1.67 & 1.06 \\
\hline 2008 & 1460 & 13754 & 11393 & 9.42 & 2.44 & 1.66 & 1.01 \\
\hline 2009 & 1476 & 13815 & 11534 & 9.36 & 2.44 & 1.63 & 0.95 \\
\hline 2010 & 1481 & 13862 & 11555 & 9.36 & 2.42 & 1.61 & 0.92 \\
\hline Total & 23259 & 221144 & 175907 & 9.51 & 2.84 & 1.53 & 0.93 \\
\hline
\end{tabular}

Panel B. Number (percentage) of directors holding multiple directorships

\begin{tabular}{cccccccc} 
Year & Only one & Two & Three & Four & Five & $\begin{array}{c}\text { More than } \\
\text { five }\end{array}$ & All \\
\hline 1996 & NA & NA & NA & NA & NA & NA & NA \\
1997 & NA & NA & NA & NA & NA & NA & NA \\
1998 & $9465(73.2)$ & $1977(15.3)$ & $930(7.2)$ & $341(2.6)$ & $131(1.0)$ & $92(0.7)$ & 12936 \\
1999 & $9215(69.5)$ & $2378(17.9)$ & $1024(7.7)$ & $405(3.1)$ & $143(1.1)$ & $95(0.7)$ & 13260 \\
2000 & $9088(70.2)$ & $2359(18.2)$ & $914(7.1)$ & $389(3.0)$ & $130(1.0)$ & $66(0.5)$ & 12946 \\
2001 & $9145(70.2)$ & $2379(18.3)$ & $951(7.3)$ & $335(2.6)$ & $150(1.2)$ & $68(0.5)$ & 13028 \\
2002 & $7448(69.7)$ & $1969(18.4)$ & $818(7.7)$ & $287(2.7)$ & $101(1.0)$ & $58(0.5)$ & 10681 \\
2003 & $7610(69.4)$ & $2121(19.4)$ & $797(7.3)$ & $282(2.6)$ & $90(0.8)$ & $59(0.5)$ & 10959 \\
2004 & $7486(67.8)$ & $2223(20.1)$ & $852(7.7)$ & $341(3.1)$ & $96(0.9)$ & $49(0.4)$ & 11047 \\
2005 & $7616(69.1)$ & $2141(19.4)$ & $839(7.6)$ & $290(2.6)$ & $97(0.9)$ & $35(0.3)$ & 11018 \\
2006 & $7299(67.1)$ & $2350(21.6)$ & $849(7.8)$ & $272(2.5)$ & $78(0.7)$ & $31(0.3)$ & 10879 \\
2007 & $6570(59.8)$ & $2588(23.6)$ & $1169(10.6)$ & $412(3.8)$ & $170(1.6)$ & $76(0.7)$ & 10985 \\
2008 & $6765(59.4)$ & $2738(24.0)$ & $1240(10.9)$ & $424(3.7)$ & $163(1.4)$ & $61(0.5)$ & 11391 \\
2009 & $6896(59.8)$ & $2815(24.4)$ & $1234(10.7)$ & $393(3.4)$ & $151(1.3)$ & $44(0.4)$ & 11533 \\
2010 & $6962(60.3)$ & $2829(24.5)$ & $1215(10.5)$ & $394(3.4)$ & $122(1.1)$ & $33(0.3)$ & 11555 \\
Total & $101565(66.7)$ & $30867(20.3)$ & $12832(8.4)$ & $4565(3.0)$ & $1622(1.1)$ & $767(0.5)$ & 152218 \\
\hline
\end{tabular}


Table 1 (Continued)

Descriptive Statistics of Directors: 1996-2010

\begin{tabular}{|c|c|c|c|c|c|c|}
\hline \multicolumn{7}{|c|}{ Panel C. Age distribution of directors } \\
\hline Year & $N$ & Mean & Median & $\begin{array}{l}\text { Standard } \\
\text { deviation }\end{array}$ & $25 \%$ & $75 \%$ \\
\hline 1996 & 11634 & 58.80 & 59 & 9.37 & 52 & 66 \\
\hline 1997 & 11977 & 58.61 & 59 & 9.38 & 52 & 65 \\
\hline 1998 & 12936 & 58.31 & 58 & 9.49 & 52 & 65 \\
\hline 1999 & 13323 & 58.27 & 58 & 9.48 & 52 & 65 \\
\hline 2000 & 12946 & 58.14 & 58 & 9.57 & 52 & 65 \\
\hline 2001 & 13034 & 58.07 & 58 & 9.63 & 52 & 65 \\
\hline 2002 & 10681 & 58.92 & 59 & 9.06 & 53 & 65 \\
\hline 2003 & 10959 & 59.19 & 59 & 8.89 & 53 & 65 \\
\hline 2004 & 11047 & 59.36 & 60 & 8.81 & 53 & 65 \\
\hline 2005 & 11018 & 59.78 & 60 & 8.67 & 54 & 66 \\
\hline 2006 & 10879 & 61.60 & 62 & 8.58 & 56 & 68 \\
\hline 2007 & 10991 & 61.12 & 61 & 8.70 & 55 & 67 \\
\hline 2008 & 11393 & 61.47 & 62 & 8.57 & 56 & 67 \\
\hline 2009 & 11534 & 61.76 & 62 & 8.58 & 56 & 68 \\
\hline 2010 & 11555 & 62.14 & 63 & 8.59 & 56 & 68 \\
\hline Total & 175907 & 59.64 & 60 & 9.17 & 53 & 66 \\
\hline \multicolumn{7}{|c|}{ Panel D. Distribution of director tenure } \\
\hline Year & $N$ & Mean & Median & $\begin{array}{l}\text { Standard } \\
\text { deviation }\end{array}$ & $25 \%$ & $75 \%$ \\
\hline 1996 & NA & NA & NA & NA & NA & NA \\
\hline 1997 & NA & NA & NA & NA & NA & NA \\
\hline 1998 & 12902 & 8.76 & 6 & 8.52 & 3 & 12 \\
\hline 1999 & 13292 & 8.63 & 6 & 8.52 & 3 & 12 \\
\hline 2000 & 12938 & 8.44 & 6 & 8.38 & 3 & 12 \\
\hline 2001 & 13034 & 9.81 & 6 & 52.99 & 3 & 12 \\
\hline 2002 & 10680 & 8.77 & 6 & 8.28 & 3 & 12 \\
\hline 2003 & 10953 & 8.70 & 6 & 8.22 & 3 & 12 \\
\hline 2004 & 11046 & 10.67 & 6 & 63.47 & 3 & 12 \\
\hline 2005 & 11014 & 8.76 & 6 & 8.24 & 3 & 12 \\
\hline 2006 & 10878 & 8.68 & 6 & 8.16 & 3 & 12 \\
\hline 2007 & 10963 & 8.59 & 6 & 8.06 & 3 & 12 \\
\hline 2008 & 11392 & 9.14 & 6 & 27.69 & 3 & 12 \\
\hline 2009 & 11532 & 8.88 & 6 & 8.03 & 3 & 12 \\
\hline 2010 & 11552 & 9.09 & 7 & 8.03 & 3 & 13 \\
\hline Total & 152176 & 8.99 & 6 & 25.36 & 3 & 12 \\
\hline
\end{tabular}

The statistics in this table are based on information on the population of all directors covered by Risk Metrics from 1996 to 2010. 
Table 2

Characteristics of Resigning Busy Directors

\begin{tabular}{ccccccc}
\hline \multicolumn{7}{c}{ Panel A. Number of remaining boards after resignation } \\
Year & $N$ & Mean & Median & $\begin{array}{c}\text { Standard } \\
\text { deviation }\end{array}$ & $25 \%$ & $75 \%$ \\
\hline 2004 & 36 & 2.778 & 2.000 & 2.307 & 1.000 & 3.500 \\
2005 & 55 & 2.745 & 2.000 & 1.965 & 1.000 & 4.000 \\
2006 & 114 & 3.895 & 3.000 & 6.103 & 2.000 & 5.000 \\
2007 & 74 & 2.716 & 2.000 & 1.531 & 1.000 & 4.000 \\
Total & 279 & 3.211 & 3.000 & 4.183 & 1.000 & 4.000 \\
\hline
\end{tabular}

Panel B. Number of other outside public company boards after resignation

\begin{tabular}{ccccccc} 
Year & $N$ & Mean & Median & $\begin{array}{c}\text { Standard } \\
\text { deviation }\end{array}$ & $25 \%$ & $75 \%$ \\
\hline 2004 & 36 & 1.694 & 1.000 & 1.091 & 1.000 & 2.000 \\
2005 & 55 & 1.745 & 1.000 & 1.174 & 1.000 & 2.000 \\
2006 & 114 & 1.991 & 2.000 & 1.068 & 1.000 & 3.000 \\
2007 & 74 & 1.703 & 1.000 & 1.056 & 1.000 & 2.000 \\
Total & 279 & 1.828 & 1.000 & 1.092 & 1.000 & 2.000 \\
\hline
\end{tabular}

Panel C. Age of resigning busy directors

\begin{tabular}{ccccccc} 
Year & $N$ & Mean & Median & $\begin{array}{c}\text { Standard } \\
\text { deviation }\end{array}$ & $25 \%$ & $75 \%$ \\
\hline 2004 & 36 & 52.139 & 51.500 & 10.074 & 45.000 & 60.500 \\
2005 & 55 & 57.582 & 58.000 & 8.200 & 52.000 & 61.000 \\
2006 & 114 & 56.482 & 58.000 & 8.596 & 50.000 & 62.000 \\
2007 & 74 & 56.405 & 57.000 & 9.403 & 52.000 & 62.000 \\
Total & 279 & 56.118 & 57.000 & 9.036 & 50.000 & 62.000 \\
\hline
\end{tabular}

Panel D. Years of tenure of resigning busy directors

\begin{tabular}{ccccccc} 
Year & $N$ & Mean & Median & $\begin{array}{c}\text { Standard } \\
\text { deviation }\end{array}$ & $25 \%$ & $75 \%$ \\
\hline 2004 & 36 & 4.194 & 4.000 & 3.206 & 1.000 & 5.500 \\
2005 & 55 & 5.909 & 4.000 & 4.873 & 2.000 & 8.000 \\
2006 & 114 & 5.105 & 4.000 & 3.947 & 2.000 & 7.000 \\
2007 & 74 & 4.568 & 3.000 & 3.527 & 2.000 & 7.000 \\
Total & 279 & 5.004 & 4.000 & 3.976 & 2.000 & 7.000 \\
\hline
\end{tabular}

Panel E. Equity holding of resigning busy directors

\begin{tabular}{ccccccc} 
Year & $N$ & $<1 \%$ & $1 \%--5 \%$ & $5 \%--10 \%$ & $10 \%--20 \%$ & $>20 \%$ \\
\hline 2004 & 36 & $30(83.3 \%)$ & $2(5.6 \%)$ & $1(2.8 \%)$ & $1(2.8 \%)$ & $2(5.6 \%)$ \\
2005 & 55 & $46(83.6 \%)$ & $4(7.3 \%)$ & $3(5.5 \%)$ & $2(3.6 \%)$ & $0(0.0 \%)$ \\
2006 & 114 & $93(81.6 \%)$ & $10(8.8 \%)$ & $4(3.5 \%)$ & $4(3.5 \%)$ & $3(2.6 \%)$ \\
2007 & 74 & $61(82.4 \%)$ & $5(6.8 \%)$ & $4(5.4 \%)$ & $2(2.7 \%)$ & $2(2.7 \%)$ \\
Total & 279 & $230(82.4 \%)$ & $21(7.5 \%)$ & $12(4.3 \%)$ & $9(3.2 \%)$ & $7(2.5 \%)$ \\
\hline
\end{tabular}


The sample of 279 resigning directors was identified from 8-K filings that report the event of director resignation during 2004-2007. We exclude 8-K reports that contain other unrelated items or are filed within 3 days of another 8-K report. We focus on directors who served (still serve) on two or more (one or more) boards of public companies before (after) the resignation. Information on the director's age, tenure, board responsibilities, and equity holding is from firms' proxy statements. 
Table 3

Declared Reasons for Resignation of Busy Directors

\begin{tabular}{|c|c|c|c|c|c|}
\hline Reasons cited for resignation & 2004 & 2005 & 2006 & 2007 & Total \\
\hline No reasons given & $11(30.56 \%)$ & $16(29.09 \%)$ & $35(30.70 \%)$ & 19 (25.68\%) & $81(29.03 \%)$ \\
\hline No disagreement & $7(19.44 \%)$ & $14(25.45 \%)$ & $30(26.32 \%)$ & $22(29.73 \%)$ & $73(26.16 \%)$ \\
\hline Other commitments & $9(25.00 \%)$ & $6(10.91 \%)$ & $24(21.05 \%)$ & $10(13.51 \%)$ & $49(17.56 \%)$ \\
\hline Personsal reasons & $4(11.11 \%)$ & $4(7.27 \%)$ & $8(7.02 \%)$ & $12(16.22 \%)$ & $28(10.04 \%)$ \\
\hline To meet independence standards & $3(8.33 \%)$ & $5(9.09 \%)$ & $7(6.14 \%)$ & $6(8.11 \%)$ & $21(7.53 \%)$ \\
\hline New appointment as executives & $1(2.78 \%)$ & $1(1.82 \%)$ & $2(1.75 \%)$ & $0(0.00 \%)$ & $4(1.43 \%)$ \\
\hline Age & $0(0.00 \%)$ & $1(1.82 \%)$ & $1(0.88 \%)$ & $1(1.35 \%)$ & $3(1.08 \%)$ \\
\hline Health reasons & $0(0.00 \%)$ & $2(3.64 \%)$ & $0(0.00 \%)$ & $1(1.35 \%)$ & $3(1.08 \%)$ \\
\hline Merger & $0(0.00 \%)$ & $0(0.00 \%)$ & $1(0.88 \%)$ & $2(2.70 \%)$ & $3(1.08 \%)$ \\
\hline To comply with other governance guidelines & $0(0.00 \%)$ & $0(0.00 \%)$ & $2(1.75 \%)$ & $1(1.35 \%)$ & $3(1.08 \%)$ \\
\hline Other reasons & $1(2.78 \%)$ & $6(10.91 \%)$ & $4(3.51 \%)$ & $0(0.00 \%)$ & $11(3.94 \%)$ \\
\hline Total & $36(100 \%)$ & $55(100 \%)$ & $114(100 \%)$ & $74(100 \%)$ & $279(100 \%)$ \\
\hline
\end{tabular}

Reasons cited for the resignation of busy directors are obtained from sample firms' 8-K filings that contain the announcement of the resignation. 
Table 4

Industry Composition of Sample Firms

\begin{tabular}{|c|c|c|c|c|c|c|c|}
\hline \multirow[b]{2}{*}{$\begin{array}{c}\text { Two-digit } \\
\text { SIC }\end{array}$} & \multirow[b]{2}{*}{ Industry description } & \multicolumn{3}{|c|}{$\begin{array}{l}\text { Firms for which busy directors resign } \\
\text { from the board ("resigned firms") }\end{array}$} & \multicolumn{3}{|c|}{$\begin{array}{l}\text { Firms for which busy directors remain } \\
\text { on the board ("retaining firms") }\end{array}$} \\
\hline & & $\begin{array}{l}\text { Number } \\
\text { of firms }\end{array}$ & $\begin{array}{l}\text { Percentage } \\
\text { in sample }\end{array}$ & $\begin{array}{l}\text { Percentage } \\
\text { in industry }\end{array}$ & $\begin{array}{l}\text { Number } \\
\text { of firms }\end{array}$ & $\begin{array}{c}\text { Percentage } \\
\text { in sample }\end{array}$ & $\begin{array}{l}\text { Percentage } \\
\text { in industry }\end{array}$ \\
\hline 10 & Metal mining & 4 & $1.4 \%$ & $0.2 \%$ & 10 & $2.2 \%$ & $0.6 \%$ \\
\hline 13 & Oil and gas extraction & 7 & $2.5 \%$ & $0.4 \%$ & 10 & $2.2 \%$ & $0.5 \%$ \\
\hline 20 & Food and kindred products & 3 & $1.1 \%$ & $0.5 \%$ & 10 & $2.2 \%$ & $1.5 \%$ \\
\hline 23 & Apparel and other finished products & 4 & $1.4 \%$ & $1.7 \%$ & 2 & $0.4 \%$ & $0.9 \%$ \\
\hline 27 & Printing, publishing, and allied & 4 & $1.4 \%$ & $1.2 \%$ & 2 & $0.4 \%$ & $0.6 \%$ \\
\hline 28 & Chemical and pharmaceutical products & 35 & $12.5 \%$ & $1.1 \%$ & 53 & $11.9 \%$ & $1.7 \%$ \\
\hline 35 & Machinery and computer equipment & 10 & $3.6 \%$ & $0.7 \%$ & 19 & $4.3 \%$ & $1.3 \%$ \\
\hline 36 & Electrical and electronics & 26 & $9.3 \%$ & $1.0 \%$ & 30 & $6.7 \%$ & $1.2 \%$ \\
\hline 37 & Transportation equipment & 7 & $2.5 \%$ & $1.1 \%$ & 8 & $1.8 \%$ & $1.3 \%$ \\
\hline 38 & Medical and scientific instruments & 11 & $3.9 \%$ & $0.6 \%$ & 20 & $4.5 \%$ & $1.1 \%$ \\
\hline 39 & Miscellaneous manufacturing industries & 1 & $0.4 \%$ & $0.4 \%$ & 7 & $1.6 \%$ & $2.9 \%$ \\
\hline 45 & Air transportation & 4 & $1.4 \%$ & $1.6 \%$ & 4 & $0.9 \%$ & $1.6 \%$ \\
\hline 48 & Communications & 16 & $5.7 \%$ & $1.2 \%$ & 16 & $3.6 \%$ & $1.2 \%$ \\
\hline 49 & Utilities & 5 & $1.8 \%$ & $0.3 \%$ & 16 & $3.6 \%$ & $1.0 \%$ \\
\hline 50 & Durable goods--wholesale & 3 & $1.1 \%$ & $0.5 \%$ & 4 & $0.9 \%$ & $0.7 \%$ \\
\hline 53 & General merchandise stores & 0 & $0.0 \%$ & $0.0 \%$ & 8 & $1.8 \%$ & $6.4 \%$ \\
\hline 57 & Home furniture and equipment store & 3 & $1.1 \%$ & $2.9 \%$ & 2 & $0.4 \%$ & $2.0 \%$ \\
\hline 58 & Eating and drinking places & 3 & $1.1 \%$ & $0.8 \%$ & 11 & $2.5 \%$ & $2.8 \%$ \\
\hline 59 & Miscellaneous retail & 6 & $2.2 \%$ & $1.2 \%$ & 9 & $2.0 \%$ & $1.8 \%$ \\
\hline 60 & Depository institutions & 10 & $3.6 \%$ & $0.3 \%$ & 14 & $3.1 \%$ & $0.4 \%$ \\
\hline 61 & Nondepository credit institutions & 6 & $2.2 \%$ & $1.3 \%$ & 7 & $1.6 \%$ & $1.5 \%$ \\
\hline 62 & Security and commodity brokers & 7 & $2.5 \%$ & $1.2 \%$ & 17 & $3.8 \%$ & $3.0 \%$ \\
\hline 63 & Insurance carriers & 18 & $6.5 \%$ & $2.1 \%$ & 21 & $4.7 \%$ & $2.4 \%$ \\
\hline 67 & Holding, other investment offices & 6 & $2.2 \%$ & $0.4 \%$ & 13 & $2.9 \%$ & $0.9 \%$ \\
\hline 73 & Computer software and data processing & 32 & $11.5 \%$ & $0.8 \%$ & 43 & $9.7 \%$ & $1.1 \%$ \\
\hline 79 & Amusement and recreation & 3 & $1.1 \%$ & $0.9 \%$ & 1 & $0.2 \%$ & $0.3 \%$ \\
\hline 80 & Health services & 4 & $1.4 \%$ & $0.8 \%$ & 11 & $2.5 \%$ & $2.3 \%$ \\
\hline 87 & Professional services & 9 & $3.2 \%$ & $1.6 \%$ & 11 & $2.5 \%$ & $2.0 \%$ \\
\hline Others & & 32 & $11 . \%$ & $0.5 \%$ & 66 & $14.8 \%$ & $1.1 \%$ \\
\hline Total & & 279 & $100.0 \%$ & NA & 445 & $100.0 \%$ & NA \\
\hline
\end{tabular}

"Percentage in sample" is the percentage ratio of the number of firms in an industry to the total number of firms in the sample. "Percentage in industry" is the percentage ratio of the number of firms in an industry to the total number of all firms in that industry over the period of 2004-2007. 
Table 5

Comparison of "Resigned" and "Retaining Firms"

\begin{tabular}{|c|c|c|c|c|c|c|}
\hline \multicolumn{7}{|c|}{ Panel A. Descriptive statistics of firms for which busy directors resign from the board ("resigned firms") } \\
\hline & $N$ & Mean & Median & $\begin{array}{l}\text { Standard } \\
\text { deviation }\end{array}$ & $25 \%$ & $75 \%$ \\
\hline Total assets & 279 & $10441.15(* * *)$ & $837.231(* * *)$ & 60417 & 205.24 & 3570.48 \\
\hline Return on assets (ROA) & 279 & -0.046 & $0.024(*)$ & 0.230 & -0.054 & 0.066 \\
\hline Sales growth rate & 279 & 0.347 & 0.117 & 1.692 & 0.010 & 0.286 \\
\hline Market-to-book & 279 & 3.994 & $2.135(* *)$ & 15.456 & 1.376 & 3.661 \\
\hline Leverage ratio & 279 & 0.583 & $0.544(*)$ & 0.367 & 0.374 & 0.747 \\
\hline Current ratio & 279 & 3.226 & $1.917 *$ & 5.265 & 1.240 & 3.322 \\
\hline Capital expenditure & 279 & $0.039(*)$ & $0.021(* * *)$ & 0.055 & 0.008 & 0.049 \\
\hline Cash flows from operation (CFO) & 279 & 0.027 & $0.063(*)$ & 0.200 & 0.004 & 0.115 \\
\hline Change in ROA & 279 & $0.029 * *$ & 0.007 & 0.260 & -0.015 & 0.032 \\
\hline Change in CFO & 279 & $0.037 *$ & 0.013 & 0.197 & -0.015 & 0.049 \\
\hline Change in leverage ratio & 279 & 0.017 & -0.005 & 0.174 & -0.041 & 0.047 \\
\hline Change in current ratio & 279 & -0.221 & -0.028 & 4.335 & -0.374 & 0.275 \\
\hline \multicolumn{7}{|c|}{ Panel B. Descriptive statistics of firms for which busy directors remain on the board ("retaining firms") } \\
\hline & $N$ & Mean & Median & $\begin{array}{l}\text { Standard } \\
\text { deviation }\end{array}$ & $25 \%$ & $75 \%$ \\
\hline Total assets & 445 & 45294.69 & 1548.93 & 210119 & 310.08 & 8680.05 \\
\hline Return on assets (ROA) & 445 & -0.024 & 0.034 & 0.267 & -0.016 & 0.082 \\
\hline Sales growth rate & 445 & 0.398 & 0.106 & 3.380 & 0.019 & 0.254 \\
\hline Market-to-book & 445 & 3.296 & 2.408 & 21.613 & 1.471 & 4.434 \\
\hline Leverage ratio & 445 & 0.624 & 0.582 & 0.367 & 0.415 & 0.791 \\
\hline Current ratio & 445 & 3.217 & 1.727 & 6.120 & 1.111 & 2.783 \\
\hline Capital expenditure & 445 & 0.047 & 0.030 & 0.061 & 0.011 & 0.060 \\
\hline Cash flows from operation (CFO) & 445 & 0.041 & 0.077 & 0.232 & 0.012 & 0.139 \\
\hline Change in ROA & 445 & -0.014 & 0.007 & 0.173 & -0.018 & 0.030 \\
\hline Change in $\mathrm{CFO}$ & 445 & 0.009 & 0.007 & 0.159 & -0.019 & 0.042 \\
\hline Change in leverage ratio & 445 & 0.028 & -0.001 & 0.184 & -0.036 & 0.050 \\
\hline Change in current ratio & 445 & -4.460 & 0.010 & 79.399 & -0.270 & 0.209 \\
\hline
\end{tabular}


Variable definitions are as follows. Total assets are the amount of total assets in millions. Return on assets (ROA) is the ratio of the firm's net income before extraordinary items to the amount of average total assets. Sales growth rate is the percentage of the firm's sales from the prior year to the current year. Market-to-book is the ratio of the firm's market value as of the fiscal year-end to the book value as of the fiscal year-end. Leverage ratio is the ratio of the firm's long-term liabilities to total assets. Current ratio is the ratio of the firm's current assets to current liabilities. Capital expenditure is the amount of capital expenditure deflated by the firm's total assets. Cash flows from operation (CFO) is the amount of cash flows from operation deflated by the firm's average total assets. Changes in ROA, CFO, leverage ratio, and current ratio are measured as the value of these ratios of the current year minus that of the prior year.

$\left({ }^{* *}\right),(* *),(*)$ indicate that the value for firms in Panel A is significantly smaller than that for firms in Panel B at the 0.001, 0.01, and 0.05 level, respectively. ***, **, * indicate that the value for firms in Panel A is significantly greater than that for firms in Panel B at the $0.001,0.01$, and 0.05 level, respectively. The differences in mean and median values are based on the $t$-test and Wilcoxon test, respectively. 
Table 6

Univariate Analysis of Market Reaction to Busy Directors' Resignation

$N$

360 3-day CAR

p-value

Panel A. All firms

Full sample

0.0040

0.051

Panel B. Firms partitioned by the characteristics of retaining firms

B1. Industry type

Firms from high-tech industries

Firms from non-high-tech industries

Difference

B2. Firm size measured by market value

Small firms

Large firms

Difference

B3. Industry overlap with the resigned firm

Firms from the same industry

Firms from a different industry

Difference
130

0.0138

0.003

230

$-0.0013$

0.273

0.0151

0.004

Panel C. Firms partitioned by the characteristics of firms from which busy directors resigned

C1. Most recent earnings change

Resigned from firm experiencing earnings decreases

180

0.0072

0.049

180

0.0009

0.271

0.0063

0.088

Resigned from firm not experiencing earnings decreases

Difference

140

0.0086

0.043

220

0.0014

0.269

0.0072

0.083

C2. Extent of analyst following

Resigned from firm with significant analyst following

269

0.0059

0.029

Resigned from firm without significant analyst following

91 
Table 6 (Continued)

Univariate Analysis of Market Reaction to Busy Directors' Resignation

\section{Panel D. Firms partitioned by the responsibilities of busy directors}

D1. The number of boards served by the resigning director

Firms with the director serving on no more than 4 boards

$\begin{array}{rrr}254 & 0.0065 & 0.023 \\ 106 & -0.0017 & 0.274 \\ & 0.0082 & 0.026\end{array}$

Firms with the director serving on more than 4 boards

Difference

$\begin{array}{ccc}74 & 0.0101 & 0.008 \\ 286 & 0.0027 & 0.157 \\ & 0.0074 & 0.063\end{array}$

D2. The responsibility of the resigning director currently being a CEO

Firms with the director currently being a CEO

Difference

$\begin{array}{rrr}127 & 0.0131 & 0.006 \\ 233 & -0.0006 & 0.396 \\ & 0.0137 & 0.006\end{array}$

D3. Role of the resigning director on audit committee

Firms with the director serving on audit committee

Firms with the director not serving on audit committee

0.0137

0.006

Difference

D4. Leadership role of the resigning director in corporate governance and control

$\begin{array}{lccc}\text { Firms with the director playing a leadership role } & 19 & 0.0200 & 0.036 \\ \text { Firms without the director playing a leadership role } & 341 & 0.0034 & 0.087 \\ \text { Difference } & & 0.0166 & 0.054\end{array}$

\section{Panel E. Firms partitioned by the expected contribution of busy directors}

$\begin{array}{lrrr}\text { Firms in the highest-highest quartile of expected contribution } & 25 & 0.0407 & 0.034 \\ \text { Firms in the medium-high quartile of expected contribution } & 21 & 0.0024 & 0.389 \\ \text { Firms in the low-medium quartile of expected contribution } & 21 & -0.0040 & 0.296 \\ \text { Firms in the lowest-lowest quartile of expected contribution } & 28 & 0.0009 & 0.401 \\ \text { Difference between highest-highest and lowest-lowest quartiles } & & 0.0398 & 0.037\end{array}$


In all panels, the three-day (i.e., days $-1,0$, and +1 centered on the announcement date of busy directors' resignation) cumulative abnormal returns (CARs) are computed by using the standard approach of event study (e.g., Brown and Warner, 1985). The abnormal returns (ARs) for each day are the difference between the firm's raw returns and the returns on the size decile portfolio to which the firm is assigned. The cumulative abnormal returns (CARs) for each firm are the sum of the abnormal returns across the three days. The $p$-value of the mean three-day cumulative abnormal returns across all sample firms is determined by following the procedure of Brown and Warner (1985). Under this approach, the standard deviation of the mean cumulative abnormal returns is estimated by using 239 days of return data (days -233 through days -6 relative to the announcement day). The test statistic controls for cross-sectional dependence in the abnormal returns because a portfolio average abnormal return is used to estimate the standard deviation. In B1, sample firms are partitioned by whether the firm is from one of the six hightech industries, including chemical and pharmaceutical (2-digit SIC of 28), computer and machinery (2digit SIC of 35), electrical and electronics (2-digit SIC of 36), transportation equipment (2-digit SIC of 37), medical and scientific instrument (2-digit SIC of 38), and computer software (2-digit SIC of 73). In B2, sample firms are partitioned by whether the firm's market value is below or above the median market value of all sample firms. In B3, sample firms are partitioned by whether the retaining firm retaining the director is from the same industry as the resigned firm associated with the director. In C1 and C2, sample firms are partitioned by whether the resigned firm experiences earnings decreases in the most recent year and whether the resigned firm has significant amount of analyst following (i.e., followed by more than two analysts), respectively. In D1, sample firms are partitioned by the total number of boards served by the director after the resignation (no more than 4 vs. more than 4). In D2, sample firms are partitioned by whether the director is currently a CEO. In D3 and D4, sample firms are partitioned by whether the director served on the audit committee of the resigned firm and chaired the corporate governance committee and/or nominating committee of the resigned firm, respectively. In Panel E, sample firms are partitioned jointly by the first two principal components based on the nine firm/director characteristics reflected in Panels B, C, and D (we use firm size measured by the firm's market value in place to the indicator for firms with market value above/below the median value). Specifically, all retaining firms are sorted into quartiles based on the first two principal components, respectively. The four groups reported in Panel E are on the main diagonal at the intersection of these quartiles. The highest-highest (lowestlowest) quartile consists of firms that are simultaneously classified into the highest (lowest) quartile of the first principal component and highest (lowest) quartile of the second principal component (i.e., the intersection of these two quartiles). Low-medium is for the second lowest quartile, whereas medium-high is for the second highest quartile. 
Table 7

Regression of Market Reaction to Busy Directors' Resignation on Firm and Director Characteristics

\begin{tabular}{|c|c|c|c|c|c|}
\hline & Model 1 & Model 2 & Model 3 & Model 4 & Model 5 \\
\hline Independent variable & $\begin{array}{c}\text { Coefficient } \\
\text { (p-value) }\end{array}$ & $\begin{array}{c}\text { Coefficient } \\
\text { ( } p \text {-value) }\end{array}$ & $\begin{array}{c}\text { Coefficient } \\
\text { ( } p \text {-value) }\end{array}$ & $\begin{array}{c}\text { Coefficient } \\
\text { ( } p \text {-value) }\end{array}$ & $\begin{array}{c}\text { Coefficient } \\
\text { (p-value) }\end{array}$ \\
\hline Intercept & $\begin{array}{c}0.030 \\
(0.082)\end{array}$ & $\begin{array}{c}0.007 \\
(0.113)\end{array}$ & $\begin{array}{c}0.003 \\
(0.490)\end{array}$ & $\begin{array}{c}0.026 \\
(0.149)\end{array}$ & $\begin{array}{c}0.008 \\
(0.034)\end{array}$ \\
\hline
\end{tabular}

Characteristics of retaining firms

$\begin{array}{lcc}\text { Industry type } & 0.015 & 0.014 \\ & (0.001) & (0.001) \\ \text { Firm size (log of market value) } & -0.002 & -0.002 \\ & (0.042) & (0.044) \\ \text { Industry overlap } & 0.005 & 0.003 \\ & (0.207) & (0.325)\end{array}$

Characteristics of resigned firms

Most recent earnings change

$\begin{array}{cc}0.007 & 0.006 \\ (0.049) & (0.099) \\ 0.009 & 0.008 \\ (0.048) & (0.057)\end{array}$

Responsibilities of busy directors

Number of boards served

$\begin{array}{cc}-0.009 & -0.009 \\ (0.051) & (0.035) \\ 0.007 & 0.007 \\ (0.052) & (0.058) \\ 0.011 & 0.010 \\ (0.009) & (0.016) \\ 0.016 & 0.016 \\ (0.031) & (0.054)\end{array}$

Index for expected contributions of busy directors

Director value index \#1

Director value index \#2

Year dummies

Included

Included

Included

Included

Included

Number of observations

360

360

360

360

360

$p$-value of $F$-statistics

0.001

0.055

0.003

0.0001

0.0001

Adj. $R^{2}$

$4.99 \%$

$1.77 \%$

$3.81 \%$

$7.59 \%$

$6.10 \%$ 
Variable definitions are as follows. The dependent variable in all regressions is the three-day cumulative abnormal returns (CARs) associated with the announcement of busy directors' resignation. The procedure for computing the three-day CARs is identical to that used in Table 6. Industry type is a dummy variable that equals one if the firm is from one of the six high-tech industries, including chemical and pharmaceutical (2-digit SIC of 28), computer and machinery (2-digit SIC of 35), electrical and electronics (2-digit SIC of 36), transportation equipment (2-digit SIC of 37), medical and scientific instrument (2-digit SIC of 38), and computer software (2-digit SIC of 73) and zero otherwise. Firm size is the firm's market value. Industry overlap is a dummy variable that equals one if the retaining firm retaining the director is from the same industry as the resigned firm associated with the director and zero otherwise. Most recent earnings change is a dummy variable that equals one if the resigned firm experiences earnings decreases in the most recent year and zero otherwise. Extent of analyst following is a dummy variable that equals one if the resigned firm has significant amount of analyst following (i.e., followed by more than two analysts) and zero otherwise. Number of boards served is a dummy variable that equals one if the total number of boards served by the director after the resignation is more than four and zero otherwise. Director being a CEO is a dummy variable that equals one if the director is currently a CEO and zero otherwise. Director's role in audit committee is a dummy variable that equals one if the director served on the audit committee of the resigned firm and zero otherwise. Director's leadership role in governance and control is a dummy variable that equals one if the director chaired the corporate governance committee and/or nominating committee of the resigned firm and zero otherwise. Director value index \#1 and director value index \#2 are the first two principal components of these nine independent variables, respectively. $p$-values for coefficients other than the intercept are one-tailed. 
Table 8

Reaction of the Investors in the "Resigned Firms"

\begin{tabular}{lccc}
\hline & $N$ & 3-day CAR & $p$-value \\
\hline Mean & 238 & 0.0086 & 0.002 \\
Median & 238 & 0.0022 & 0.018 \\
\hline
\end{tabular}

The three-day (i.e., days $-1,0$, and +1 centered on the announcement date of busy directors' resignation) cumulative abnormal returns (CARs) are computed by using the standard approach of event study (e.g., Brown and Warner, 1985). The abnormal returns (ARs) for each day are the difference between the firm's raw returns and the returns on the size decile portfolio to which the firm is assigned. The cumulative abnormal returns (CARs) for each firm are the sum of the abnormal returns across the three days. The $p$-value of the mean three-day cumulative abnormal returns across all sample firms is determined by following the procedure of Brown and Warner (1985). Under this approach, the standard deviation of the mean cumulative abnormal returns is estimated by using 239 days of return data (days -233 through days -6 relative to the announcement day). The test statistic controls for cross-sectional dependence in the abnormal returns because a portfolio average abnormal return is used to estimate the standard deviation. 
Table 9

Analysis of One-year-ahead Excess Stock Returns of "Retaining Firms”

\begin{tabular}{|c|c|c|}
\hline & Model 1 & Model 2 \\
\hline Independent variable & $\begin{array}{c}\text { Mean } \\
\text { coefficient } \\
\text { (p-value) }\end{array}$ & $\begin{array}{c}\text { Mean } \\
\text { coefficient } \\
\text { ( } p \text {-value) }\end{array}$ \\
\hline \multicolumn{3}{|c|}{ Panel A. Regression results for the retaining firms } \\
\hline $\operatorname{Ln}(\mathrm{MV})$ & $\begin{array}{c}-0.001 \\
(0.134)\end{array}$ & $\begin{array}{c}-0.001 \\
(0.122)\end{array}$ \\
\hline $\operatorname{Ln}(\mathrm{B} / \mathrm{M})$ & $\begin{array}{c}0.002 \\
(0.069)\end{array}$ & $\begin{array}{c}0.002 \\
(0.071)\end{array}$ \\
\hline Ret_1 & $\begin{array}{l}-0.021 \\
(0.023)\end{array}$ & $\begin{array}{l}-0.021 \\
(0.023)\end{array}$ \\
\hline Ret_2 & $\begin{array}{c}0.006 \\
(0.038)\end{array}$ & $\begin{array}{c}0.006 \\
(0.038)\end{array}$ \\
\hline Ret_3 & $\begin{array}{c}-0.001 \\
(0.073)\end{array}$ & $\begin{array}{c}-0.001 \\
(0.074)\end{array}$ \\
\hline RESIGN & $\begin{array}{c}0.013 \\
(0.019)\end{array}$ & $\begin{array}{c}0.021 \\
(0.048)\end{array}$ \\
\hline Director value index \#1 & - & $\begin{array}{c}0.026 \\
(0.033)\end{array}$ \\
\hline Director value index \#2 & - & $\begin{array}{c}0.023 \\
(0.028)\end{array}$ \\
\hline \multicolumn{3}{|c|}{ Panel B. Regression results for the resigned firms } \\
\hline $\operatorname{Ln}(\mathrm{MV})$ & $\begin{array}{c}-0.001 \\
(0.127)\end{array}$ & $\begin{array}{c}-0.001 \\
(0.127)\end{array}$ \\
\hline $\operatorname{Ln}(B / M)$ & $\begin{array}{c}0.002 \\
(0.076)\end{array}$ & $\begin{array}{c}0.002 \\
(0.075)\end{array}$ \\
\hline Ret_1 & $\begin{array}{l}-0.018 \\
(0.039)\end{array}$ & $\begin{array}{c}-0.019 \\
(0.038)\end{array}$ \\
\hline Ret_2 & $\begin{array}{c}0.006 \\
(0.038)\end{array}$ & $\begin{array}{c}0.006 \\
(0.037)\end{array}$ \\
\hline Ret_3 & $\begin{array}{c}-0.001 \\
(0.076)\end{array}$ & $\begin{array}{c}-0.001 \\
(0.077)\end{array}$ \\
\hline RESIGN & - & $\begin{array}{c}0.002 \\
(0.349)\end{array}$ \\
\hline
\end{tabular}


Variable definitions are as follows. In Panels A and B, the dependent variable of the regression is firms' monthly returns over the next 12-month period. For the retaining firms (Panel A) and resigned firms (Panel B), this is the 12-month period subsequent to the busy director's resignation. The independent variables include the logarithm of the firm's market value $(\log (\mathrm{MV}))$, the logarithm of the firm's book-to-market ratio $(\log (\mathrm{B} / \mathrm{M}))$ as of the end of the most recent fiscal-year, the return of the prior month (Ret_1), the return of the previous 12-month period (Ret_2), the return of the previous 36-month period (Ret_3), the dummy variable for busy directors' resignation (RESIGN) that equals one for the retaining firm (Panel A) and the resigned firm (Panel B) and zero otherwise, and the director value index \#1 and \#2 (Panel A only), which are the first two principal components derived from the nine independent variables included in the regression of Table 7. The regression in Panel A includes firms that keep the busy directors (i.e., the retaining firms) and all other firms. The regression in Panel B includes firms from which the busy directors resign (i.e., the resigned firms). In Panel A, the variables of RESIGN, director value index \#1, and director value index \#2 all take the value of zero for firms other than the retaining firms. In Panel B, the variable of RESIGN takes the value of zero for firms other than the resigned firms. The regression period is from March, 2004 through December, 2008 (the first event of busy directors' resignation occurred in February, 2004). p-values are one-tailed. 
Table 10

Change in Busy Directors’ Responsibilities after Resigning from the Resigned Firm

\begin{tabular}{|c|c|c|c|c|c|c|}
\hline \multicolumn{7}{|c|}{ Panel A. Mean (median) number of committee positions on the retaining firms' board } \\
\hline & $N$ & $\begin{array}{l}\text { Year before } \\
\text { resignation } \\
\text { (year t-1) }\end{array}$ & $\begin{array}{c}\text { Year after } \\
\text { resignation } \\
(\text { year } t+1)\end{array}$ & $\begin{array}{c}\begin{array}{c}\text { Difference } \\
(\text { year } t+1\end{array} \\
\text { minus year } t-1)\end{array}$ & $\begin{array}{c}p \text {-value of } \\
\text { mean } \\
\text { difference }\end{array}$ & $\begin{array}{c}p \text {-value of } \\
\text { median } \\
\text { difference }\end{array}$ \\
\hline Chair of audit and/or compensation committees & 134 & $\begin{array}{c}0.239 \\
(0.000)\end{array}$ & $\begin{array}{c}0.314 \\
(0.000)\end{array}$ & $\begin{array}{c}0.075^{* * *} \\
(0.000)^{* *}\end{array}$ & 0.006 & 0.011 \\
\hline Audit committee chair or member & 134 & $\begin{array}{c}0.373 \\
(0.000)\end{array}$ & $\begin{array}{c}0.388 \\
(0.000)\end{array}$ & $\begin{array}{c}0.015 \\
(0.000)\end{array}$ & 0.298 & 0.395 \\
\hline Compensation committee chair or member & 134 & $\begin{array}{c}0.455 \\
(0.000)\end{array}$ & $\begin{array}{c}0.507 \\
(0.000)\end{array}$ & $\begin{array}{c}0.052^{*} \\
(0.000)^{*}\end{array}$ & 0.073 & 0.074 \\
\hline Governance committee chair or member & 134 & $\begin{array}{c}0.597 \\
(0.000)\end{array}$ & $\begin{array}{c}0.694 \\
(0.000)\end{array}$ & $\begin{array}{c}0.097^{*} \\
(0.000)^{*}\end{array}$ & 0.062 & 0.084 \\
\hline All committee positions & 134 & $\begin{array}{c}1.425 \\
(1.000)\end{array}$ & $\begin{array}{c}1.590 \\
(1.000)\end{array}$ & $\begin{array}{c}0.165^{* *} \\
(0.000)^{* *}\end{array}$ & 0.019 & 0.021 \\
\hline \multicolumn{7}{|c|}{ Panel B. Mean (median) number of directorships immediately after resignation vs. a year after resignation } \\
\hline & $N$ & $\begin{array}{c}\text { Year of } \\
\text { resignation } \\
\text { (year t) }\end{array}$ & $\begin{array}{c}\text { Year after } \\
\text { resignation } \\
(\text { year } t+1)\end{array}$ & $\begin{array}{c}\begin{array}{c}\text { Difference } \\
(\text { year } t+1 \\
\text { minus year } t)\end{array} \\
\end{array}$ & $\begin{array}{c}p \text {-value of } \\
\text { mean } \\
\text { difference }\end{array}$ & $\begin{array}{c}p \text {-value of } \\
\text { median } \\
\text { difference }\end{array}$ \\
\hline Number of directorships per director & 210 & $\begin{array}{c}1.881 \\
(1.000)\end{array}$ & $\begin{array}{c}1.562 \\
(1.000)\end{array}$ & $\begin{array}{l}-0.319 * * * \\
(0.000)^{* * *}\end{array}$ & $<0.0001$ & $<0.0001$ \\
\hline
\end{tabular}

***, **, * denotes statistical significance (one-sided) at the $0.01,0.05$, and 0.1 level, respectively. 
Table 11

Regression for the Optimal Number of Board Seats for Busy Directors

\begin{tabular}{lc}
\hline Independent variable & $\begin{array}{c}\text { Coefficient } \\
(p \text {-value })\end{array}$ \\
\hline Intercept & -0.003 \\
& $(0.671)$ \\
Number of board seats after resignation & \\
Two board seats & 0.005 \\
Three board seats & $(0.268)$ \\
& 0.015 \\
Four board seats & $(0.023)$ \\
& 0.009 \\
Five board seats & $(0.130)$ \\
Six board seats & -0.004 \\
& $(0.388)$ \\
Seven board seats & -0.003 \\
Eight or more board seats & $(0.392)$ \\
Year dummies & -0.002 \\
Number of observations & $(0.428)$ \\
Modified director value index $\# 1$ & -0.001 \\
& $(0.456)$ \\
& \\
&
\end{tabular}


Variable definitions are as follows. The dependent variable of the regression is the three-day cumulative abnormal returns (CARs) associated with the announcement of busy directors' resignation. The procedure for computing the three-day CARs is identical to that used in Table 6. The number of board seats (two through eight or more board seats) is the number of directorships kept by the director after the resignation. Modified director value index \#1 (modified director value index \#2) is the first (second) principal component of the independent variables in Table 6 other than the number of boards served. $p$ values for coefficients other than the intercept are one-tailed. 